\title{
Comparative Characteristics of Dances in China and Ukraine from the Point of View of Historical, Genre, Target, Methodological and Socio-Political Aspects: a Review Article
}

\author{
Zhang G. ${ }^{1,2}$ ABCD \\ ${ }^{1}$ Lishui University \\ ${ }^{2}$ H. S. Skovoroda Kharkiv National Pedagogical University
}

Authors' Contribution: A - Study design; B - Data collection; C - Statistical analysis; D - Manuscript Preparation; E - Funds Collection

Corresponding author: Zhang G., ORCID: 0000-0002--7725, Xueyuan Road, Lishui, Zhejiang, China, 323000, razumenkot@gmail.com

DOI: https://doi.org/10.34142/HSR.2021.07.03.05

How to Cite

Zhang G. Comparative Characteristics of Dances in China and Ukraine from the Point of View of Historical, Genre, Target, Methodological and Socio-Political Aspects: a Review Article. Zdorov'â, sport, reabilitaciâ [Health, Sport, Rehabilitation]. 2021;7(3):76-89. https://doi.org/10.34142/HSR.2021.07.03.05

\begin{abstract}
Purpose: to compare target, style, methodological, historical and socio-political features and determine the possibilities of mutual application of various approaches to the development of dance education in China and Ukraine.

Material and methods. The review included articles on the peculiarities of historical development, methodological aspects, the dance influence on health of people of different ages and different social status. The review also included articles on the peculiarities of the social and political aspects of dance art in China and Ukraine. The analysis of literary sources was carried out by working with scientific articles that are presented in the databases "Web of Science", "Scopus", "Pub Med" and others.

Results. The features of Chinese dances that can be applied in Ukraine have been identified: 1 - the practice of mass dances on the streets and squares of cities; 2 - the inner orientation of the dance art towards unity with nature, towards the self-expression of people of their feelings, emotions, experiences, towards achieving harmony through movement; 3 - increased attention to the psychological preparation of dancers; 4 - high attention of researchers to the influence of dancing on the mental and cardiological health of people of different ages; 5 - high number of articles, published in rating journals. The features of Ukrainian dances, which can be applied in China, have been determined: 1 - the development of speed-power qualities of dancers; 2 - implementation of an individual approach, which is currently beginning to develop in Ukraine.

Conclusions. The combination of Ukrainian speed-power dance and Chinese inner focus on harmony of body and soul, on unity with nature will create a qualitatively new approach to the development of dance art in general and to the process of teaching dance. This study is the first from the point of view of a comparative analysis of the process of teaching dance in China and Ukraine in terms of historical, socio-political, methodological, substantive aspects, as well as the impact of dancing on the body of the practitioners.
\end{abstract}

Keywords: choreography, training, teaching, students, dance styles 


\title{
Анотація
}

Чжан Г. Порівняльна характеристика танців в Китаї і в Україні з точки зору історичного, жанрового, цільового, методичного та суспільно-політичного аспектів: оглядова стаття

Мета: порівняти цільові, стильові, методичні, історичні та суспільно-політичні особливості і визначити можливості взаємного застосування різних підходів до розвитку танцювального освіти в Китаї і в Україні.

Матеріал і методи. В огляд було включено статті, присвячені особливостям історичного розвитку, методичних аспектів, впливу танців на здоров'я людей різного віку і різного соціального стану. Також в огляд були включені статті, присвячені особливостям суспільних і політичних аспектів танцювального мистецтва в Китаї і в Україні. Аналіз літературних джерел проводився шляхом роботи з науковими статтями, які представлені в базах даних «Web of Science», «Scopus», «Pub Med» та інших.

Результати. Виявлено особливості китайських танців, які можуть бути застосовані в Україні: 1 - практика масових танців на вулицях і площах міст; 2 - внутрішня спрямованість танцювального мистецтва на єдність 3 природою, на самовираження людей своїх почуттів, емоцій, переживань, на досягнення гармонії через рух; 3 - підвищена увага до психологічної підготовки танцюристів; 4 - висока увага дослідників до впливу танців на ментальне і кардіологічне здоров'я людей різного віку; 5 - відносно висока кількість статей, опублікованих в рейтингових журналах. Визначено особливості українських танців, які можуть бути застосовані в Китаї: 1 - розвиток швидкісносилових якостей танцюристів; 2 - реалізація індивідуального підходу, який в даний час починає розвиватися в Україні.

Висновки. Поєднання українського швидкісно-силового танцю і китайської внутрішньої спрямованості на гармонію душі і тіла, на єдність з природою створить якісно новий підхід до розвитку танцювального мистецтва в цілому і до процесу навчання танцям. Дане дослідження є першим з точки зору порівняльного аналізу процесу навчання танцям в Китаї і в Україні по історичним, суспільно-політичним, методичним, змістовним аспектам, а також - за впливом танців на організм тих, хто займається танцями.

Ключові слова: хореографія, тренування, викладання, студенти, танцювальні стилі

\begin{abstract}
Аннотация
Чжан Г. Сравнительная характеристика танцев в Китае и в Украине с точки зрения исторического, жанрового, целевого, методического и общественно-политического аспектов: обзорная статья

Цель: сравнить целевые, стилевые, методические, исторические и общественно-политические особенности и определить возможности взаимного применения различных подходов к развитию танцевального образования в Китае и в Украине.

Материал и методы. В обзор были включены статьи, посвященные особенностям исторического развития, методических аспектов, влияния танцев на здоровье людей разного возраста и разного социального положения. Также в обзор были включены статьи, посвященные особенностям общественных и политических аспектов танцевального искусства в Китае и в Украине. Анализ литературных источников проводился путем работы с научными статьями, которые представлены в базах данных «Web of Science», «Scopus», «Pub Med» и других.

Результаты. Выявлены особенности китайских танцев, которые могут быть применены в Украине: 1 - практика массовых танцев на улицах и площадях городов; 2 - внутренняя направленность танцевального искусства на единство с природой, на самовыражение людей своих чувств, эмоций, переживаний, на достижение гармонии через движение; 3 - повышенное внимание к психологической подготовке танцоров; 4 - высокое внимание исследователей к влиянию танцев на ментальное и кардиологическое здоровье людей разного возраста; 5 относительно большое количество статей, опубликованных в рейтинговых журналах. Определены особенности украинских танцев, которые могут быть применены в Китае: 1 - развитие скоростно-силовых качеств танцоров; 2 - реализация индивидуального подхода, который в настоящее время начинает развиваться в Украине.

Выводы. Сочетание украинского скоростно-силового танца и китайской внутренней направленности на гармонию души и тела, на единство с природой создаст качественно новый подход к развитию танцевального искусства в целом и к процессу обучения танцам. Данное исследование является первым с точки зрения сравнительного анализа процесса обучения танцам в Китае и в Украине по историческим, общественнополитическим, методическим, содержательным аспектам, а также - по влиянию танцев на организм занимающихся.
\end{abstract}

Ключевые слова: хореография, тренировка, преподавание, студенты, танцевальные стили 


\section{Introduction}

Dances from ancient times to the present in an amazing way combine movement and the inner world of a person [1]. In its development, dances reflect history, socio-political changes, cultural trends, the general nature of movements and education in general. Dancing is one of the most attractive forms of art, recreation, entertainment, physical activity [2]. The dancing art has developed in different parts of the world, so dances have certain differences in their content, focus and aim. In this regard, a comparison of various aspects of dancing that have arisen in different parts of the world is interesting from the point of view of the scientific understanding of dance art, the characteristics of movements, the role of dancing in education, sports, as well as in the treatment of various physical and psychological disorders with the help of movements. Also, such a comparison can give an understanding of the prospects for the development of dance in different countries. This provision is of particular relevance at the present time - during the period of unification of the achievements of different countries.

Currently, there is a mutual integration of the economy, scientific knowledge, cultural achievements of different countries. Integration between the countries of the West and the East is of particular relevance due to the existing differences in culture, history, and peculiarities of mentality [1]. From this point of view, an urgent issue at the present time for the further development of the achievements of the peoples of the East and West is the study of the peculiarities of culture, science, education of different countries of the eastern and western regions. The country that most fully reflects the peculiarities of science, culture and education of the East is China. For comparison with the peculiarities of the development of science, culture, education, any country in the western region can be chosen. It is relevant to compare the country of the East, for example, China, and a country that has absorbed in the process of its development both the features of the West and the features of the East. One of these countries is Ukraine [2]. Ukraine also has its own distinctive traditions that make it unique for both Western and Eastern countries. Therefore, a comparison of Ukraine and China from the point of view of the peculiarities of the achievements of culture, science, education can provide a key to understanding the tendencies of mutual integration of East and West. In this regard, the choice for such a comparison of countries such as China and
Ukraine is quite reasonable. Dances can be selected as a subject for comparison, since dances reflect the history of the development of countries, the peculiarities of the culture of movements, teaching and research directions in the field of promoting and maintaining health.

China is currently developing rapidly and is competing with the world's leading powers in the economy, education, science, sports, and art. There is an opinion [3] that the rapid development of China is significantly influenced by ancient philosophy, which is relevant to the present. Since ancient times, the Chinese civilization has been characterized by a focus on achieving happiness and well-being in earthly life. At the same time, it is believed that the fate of a person depends not on divine predestination, but on his own efforts. This philosophical position determines the attitude of people to the activities in which they are engaged. Dancing is no exception.

Dance in China is a very diverse art form with many contemporary and traditional dance genres. The dances cover a wide spectrum, from folk dances to performances in the theater of opera and ballet, and can be used in public celebrations, rituals and ceremonies. The most famous Chinese dances are the dragon dance and the lion dance [4]. The recorded history of various forms of dance in China is quite ancient. The earliest Chinese character for dance, written on oracle bones, represents a dancer holding oxtails. Some modern Chinese dances, such as long-sleeved dances, were recorded in the earliest periods. Many folk dances have a long history. It can be folk dances, or dances that were once performed as rituals or as performances - some could be danced at court. Among the most famous Chinese traditional dances are the dragon dance and the lion dance, both of which are known in earlier dynasties in various forms.

In China, dance was also used as an exercise for people to stay healthy after prolonged wet weather. Traditionally, some Chinese dances are also associated with martial arts, and are used to practice martial arts as well as fitness. Some exercises in martial arts such as Taijiquan are similar to choreographic dances. In modern China, you can often see people using dance as a form of training and psychological relaxation in parks, streets and squares of the city [4].

In Ukraine, dancing is also a very common form of recreation, entertainment and performing arts [1]. Ukrainian folk dances are notable for their ardent passion, transitions to climaxes, original multi-colored costumes. Many dances in Ukraine 
also originated as martial arts (hopak) movements. At first, the hopak was a kind of warm-up, during which the Cossacks honed their combat skills. Subsequently, this dance has spread and gained popularity among various categories of the population. Movements in Ukrainian dances require good physical fitness.

Thus, the dances of China and Ukraine have many of their own characteristics, which are reflected in the methods of teaching dance, as well as in the areas of scientific research in the field of physical activity, health, rehabilitation, and physical therapy. Therefore, a comparison of the dances of China and Ukraine in terms of the features of historical formation, content, teaching methods and the direction of scientific research is of great importance for determining the possibilities of developing dance art as a type of physical activity and mutual integration of experience in this area.

Purpose: to compare aims, styles, methodological, historical and socio-political features and determine the possibilities of mutual application of various approaches to the development of dance education in China and Ukraine.

\section{Material and methods}

\section{Eligibility criteria}

The review included articles on the peculiarities of historical development, methodological aspects, the impact on health of people of different ages and different social status. The review also included articles on the peculiarities of the social and political aspects of dance art in China and Ukraine. For selection, articles had to be written in English and published in peer-reviewed journals with the full version of the article available. All entries were allowed. Works that did not fit the purpose of this study were excluded.

\section{Sources of information and search strategy}

The analysis of literary sources was carried out by working with scientific works that are presented in the databases "Web of Science", "Scopus", "Pub Med" and others. The search for literary sources was carried out using the keywords "dancing", "teaching dance", "choreography". Further, the results were refined for the keyword "China" and separately - for the keyword
"Ukraine". For the results for the keyword "China", the refinement was carried out by publication years from 2019 to 2021.

\section{Study selection}

The selection was made as follows: first, the topic of the article was analyzed, then, if the topic corresponded to the direction of our research, the abstract was analyzed. If the abstract corresponded to the direction of our research, the text of the article was analyzed. Also, when analyzing literary sources, preference was given to the sources presented in quarters 1-3 of levels "Web of Science" and "Scopus". If any of the selection criteria were not met, the article was excluded from the systematic review. In case of doubt, the article was discussed with experts (Zhanneta Kozina, Vitalii Korobeinik) until a consensus was reached.

\section{Results}

As a result of a search conducted on the keyword "dancing", 41675 sources were found and 1297 sources were found on the keyword "dance training". After specifying the word "China", 1472 sources were found. For the years of publication from 2019 to 2021, 126 sources were selected, of which, after analyzing the text of articles for this review, 46 sources were left. Also, after clarification on the keyword "Ukraine", 27 sources were found, of which 8 sources were left for this review. Due to the fact that a small number of scientific works were found to analyze studies on this issue in relation to Ukraine, clarification by years of publications regarding Ukraine was not applied. A total of 54 sources were selected for this review.

Thus, this problem is presented in the modern scientific literature of the world ranking much wider in China in comparison with studies on Ukraine. Of the selected sources regarding China, $10(21.7 \%)$ were devoted to the study of the historical features of the development of dance art in China, 2 (4.3\%) - socio-political factors, 20 (43.5\%) - the impact of dancing on the health of people of different age, $13(28,3 \%)$ - methods of teaching dance and $1(2.2 \%)$ source was devoted to the study of dance styles (Table 1). Concerning Ukraine, 3 (37.5\%) sources were devoted to sociopolitical factors in the development of dance art, 3 $(37.5 \%)$ sources - the study of dance styles and 2 $(25 \%)$ sources - the methodology of teaching dance art (Table 1). It should be noted that in the studies 
of Jordan [2], Stepanyuk [5], Wilson [6], dance styles are considered. However, at the same time, the problems of the historical development of dance art in Ukraine are also partially touched upon. In the studies of Maryna [7], Pyatnickaya [8], the methods of teaching dance are considered, however, these works also partially touch upon the issues of the influence of dancing on the health of the surveyed people.

Quantitative and qualitative analysis of modern scientific sources based on the data of world ranking scientific bases on the problem of comparing dance education in China and Ukraine

\begin{tabular}{|c|c|c|c|c|c|c|}
\hline \multirow[b]{2}{*}{$\begin{array}{l}\text { Direction of } \\
\text { research }\end{array}$} & \multicolumn{3}{|l|}{ China } & \multicolumn{3}{|c|}{ Ukraine } \\
\hline & Authors & 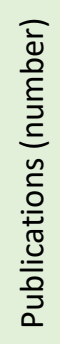 & 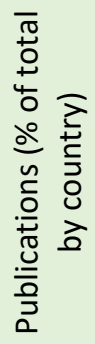 & Authors & 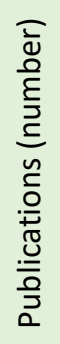 & 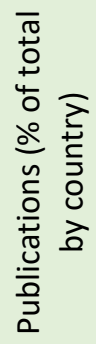 \\
\hline $\begin{array}{c}\text { Historical features } \\
\text { of the } \\
\text { development of } \\
\text { dance art }\end{array}$ & $\begin{array}{l}\text { Dambricourt-Malasse et.al., 2019; Fang } \\
\text { et.al., 2020; Hyun et.al., 2020; Jeon et.al., } \\
\text { 2020; Jin et.al., 2019; Jongjin, 2020; Kim, } \\
\text { 2019; Mengni et.al., 2020; Ouyang et.al., } \\
\text { 2020; SeongHee, } 2019\end{array}$ & 10 & 21,7 & $\begin{array}{l}\text { Partially: Jordan, } \\
\text { 2014; Stepanyuk, } \\
\text { 2016; Wilson, } \\
2004\end{array}$ & - & - \\
\hline $\begin{array}{l}\text { Socio-political } \\
\text { factors in the } \\
\text { development of } \\
\text { dance art }\end{array}$ & Chen et.al., 2021; Heyang et.al., 2021 & 2 & 4,3 & $\begin{array}{l}\text { Aleksandr, 2018; } \\
\text { Gershenson, 2019; } \\
\text { Zhuk, } 2020\end{array}$ & 3 & 37,5 \\
\hline $\begin{array}{c}\text { The impact of } \\
\text { dancing on the } \\
\text { health of people of } \\
\text { different ages }\end{array}$ & $\begin{array}{l}\text { Avaunt, 2021; Chang, 2021; Dang et.al., } \\
\text { 2020; Deng et.al., 2019; Ding et.al., 2021; } \\
\text { Jung et. al., 2021; Jiang et.al., 2021; Liao } \\
\text { et.al., 2019; Liao et.al., 2020; Liyansen et.al., } \\
\text { 2021; Peng et.al., 2020; Peng et.al., 2021; Qi } \\
\text {, 2021; SerlinSerlin, 2021; Tong et.al., 2021; } \\
\text { Wang et.al., 2019; Xu et.al., 2019; Zhang } \\
\text { et.al., 2021; Zhang et.al., 2019; Zhao et.al., } \\
2021\end{array}$ & 20 & 43,5 & $\begin{array}{l}\text { Partially: Maryna, } \\
\text { 2015; Pyatnickaya, } \\
2015\end{array}$ & - & - \\
\hline $\begin{array}{c}\text { Dance teaching } \\
\text { method }\end{array}$ & $\begin{array}{l}\text { Heyang et.al., 2020; Hong et.al., 2019; } \\
\text { Huang et.al., 2021; Jinjing, 2019; Kim, 2020; } \\
\text { Liu, 2019; Ma et.al., 2019; Rowe et.al, 2020; } \\
\text { Rowe et.al., 2020; Xiao, 2021; You, 2020; } \\
\text { Xiaofei et.al., 2021; Kozina et.al., } 2021\end{array}$ & 13 & 28,3 & $\begin{array}{l}\text { Maryna, 2015; } \\
\text { Pyatnickaya, } 2015\end{array}$ & 2 & 25 \\
\hline Dance styles & Hee et.al., 2019 & 1 & 2,2 & $\begin{array}{l}\text { Jordan, 2014; } \\
\text { Stepanyuk, 2016; } \\
\text { Wilson, } 2004\end{array}$ & 3 & 37,5 \\
\hline Sum & - & 46 & 100 & - & 8 & 100 \\
\hline Total & & 54 & & & & \\
\hline
\end{tabular}

\section{Historical features of the development of dance art in China and Ukraine}

Most researchers associate the origin of dances in China with various shamanic practices for communicating with spirits when it is necessary to solve practical problems: success in hunting, a good harvest, victory in a war, treatment of diseases, and others. Thus, in the work of
Dambricourt-Malasse et al. [9] a parallel is drawn between agro-pastoral rituals and shamanic dances, as reflected in the cave paintings on Red Rock. Red Rock is one of the earliest known rock art sites in China. The work [9] presents the results of a study of some of the frescoes. These murals show the light ritual shamanic dance practices of the agropastoralist peoples prior to rice cultivation. The frescoes show the connection with the spirits of 
animals, the symbols of which are the buffalo and the python. In the above study [9], three scenes are described. These scenes are interpreted in the historical context of ethnic minorities and their cultural traditions, devoid of writing. They were named "Shamanic Dance", "Dance Lesson" and "Meeting".

Fang, Ryu [3] also point to the shamanic origin of dance in China, describing the influence of Chinese dance on the culture of Korea. These authors emphasize that in Chinese dances one can see the spirit to which people aspired as an aesthetic ideal. This spirit was reflected in their dance and manifested by merging with shamanism. The authors also note the influence of Chinese culture on shamanistic motives in Korean music. The main meaning of shamanic dances in China, according to the authors, consists in the following provisions: 1 - heaven and people are one as an aesthetic ideal; 2 - serenity lies in movement; 3 breathing and psychokinesis, as well as body and soul, are in harmony. Thus, we see the focus of Chinese dances on the inner world of a person, on his spiritual development, on achieving harmony between the internal and the external.

Hyun et.al. [10] based on the analysis of sword dances, they consider the origin and development of two peoples - Chinese and Korean. The authors concluded that the historical roots of the origin of the two peoples are based on behavior in ancient times and begin with human instincts such as hunting, war, and sacrifice. The authors also point out that both cultures have preserved ancient traditions of sword dancing, although there are some innovations. Innovation is expressed in some of the movements and appearance of the swords. Also, these authors note that the dance with two swords arose as an expression of joy after the hunt.

In a number of studies $[4,11,12]$, the focus of Chinese dances on the inner world of a person, to achieve harmony in thoughts and emotions and movements, has been traced to this day. This observation is based on observing the development of dance in a historical context. Thus, Jeon, GwiYoung [4] found that the use of folk dances by older women who migrated from China to Korea helps them to normalize emotions through the memories that accompany the performance of folk dances. Thus, in Chinese dances, the main direction that can be traced from the analysis of historical traditions is the focus on the inner world of a person, bringing to a certain harmony of feelings, thoughts, emotions in accordance with the harmony and unity of nature.
The works $[13,14]$ show the development of dance art from traditional to innovative and then again to the preservation of traditional elements. This development is shown depending on the rule of various dynasties. It is noted that the preservation of the traditional elements of the dance is based on the preservation of the transmission of the inner world of the dancer in combination with the tasks of the outer world. The preservation of ancient traditions in Chinese dance is also noted by Ouyang and Sook [15], describing the lion dance as a manifestation of the power and contentment of the gods who visited people. Thus, despite the presence of many innovations in the dance art of China, the shamanic orientation of dances and their focus on expressing unity with nature and with the inner world of man remains relevant. SeongHee [16] describes the history of one of the most popular dances in China and points out that one of the inner meanings of this dance is to express a person's magnificent and vibrant lifestyle and vision of the future through folding fans.

Thus, the historical analysis of the development of dances in China showed the following: 1 - the preservation of the shamanistic orientation of dances to the present time; 2 maintaining focus on the inner world of a person, on harmony with nature, on spiritual development, on understanding one's purpose in this world with deep mental concentration in movements.

The history of Ukrainian dance is reflected in modern scientific literature much less than the history of Chinese dance. Researchers point to a lack of ethnographic research on Ukrainian dances. Nevertheless, in work [6] it is noted that on the territory of Ukraine the first dances arose as a way of communication between people, as well as between people and gods. Dancing movements also developed as a result of the imitation of the movements of animals, birds, and later - gestures that reflected certain labor processes (for example, some round dances). The original dance, like the song, played a magical role, therefore, among the calendar-ritual dances, almost the most archaic features have been preserved.

The oldest traces of dance art in Ukraine can be considered drawings of the Trypillian era, which depicts the figures of people who put one hand on the waist, and the other lead behind the head [6]. Such movements are found in modern dances [5]. There are images of dancers and musicians on the frescoes of St. Sophia Cathedral in Kiev in the 11th century. According to some researchers [6], silver figurines of men from the 
Martynov treasure of the 4th century convey one of the dance movements: in a half-squat with legs wide apart and hands laid on the hips. Images of dances are also found in many miniatures from ancient chronicles. Written messages about ancient dances are given to us by chroniclers who call them "jumping and trampling", "gulba and dancing", "wobbling ridge", "dancing and splashing". Christian chroniclers call such actions "demonic" or "pagan" [6]. This gives some reason to believe that primitive dances were closely associated with ancient worship. It is possible that Christian influence contributed to the fact that, with the historical development of Ukrainian dance, the original shamanic orientation of the dance turned out to be hidden. This is the main distinguishing feature of the Ukrainian dance from the Chinese: the traditional orientation of the dance has been preserved in the Chinese culture.

Historical analysis of the dance art in Ukraine allows us to highlight the main features of Ukrainian dance. These features arose with the emergence of dances in Ukraine and have survived to this day. They are as follows: 1 - the presence of very energetic movements, requiring the development of strength, speed, endurance; the presence of movements requiring a high development of coordination in combination with a high level of speed-strength qualities. This position is not typical for the majority of Chinese dances, in which smoothness and flexibility are manifested mainly; 2 - focus on interacting with the outside world, to protect their values or to conquer the surrounding space. This leads to energetic movements in Ukrainian dances. It is no coincidence that Ukrainian dance gave rise to modern Finnish rock [1].

\section{Socio-political factors in the development of dance art in China and Ukraine}

Analysis of socio-political factors in the development of dance art in China and Ukraine showed that events in society have a great impact on art, including dance. So, in China, dance dramas were created, reflecting the processes taking place during the revolution [17]. The revolution also had a very strong impact on dance in Ukraine [18]. In addition, Ukraine is also characterized by the influence of public life in general on the art of dancing [18]. Research is also being carried out in China to determine the impact of the economy on the development of dance teaching [19]. As for Ukraine, there is a great influence of Jewish intervention in the development of dancing [20].
The impact of dancing on the health of people of different ages

The influence of Chinese dances on the health of people of different ages is considered from several positions: 1 - the effectiveness of dancing on squares, which are very popular in China, for the mental, mental and physical health of middle-aged and elderly people; 2 - the influence of the process of teaching dance on the competence of dancers and teachers; 3 - the effectiveness of the use of dancing in physical therapy and rehabilitation.

A number of studies [21-25] are devoted to dancing on the streets and squares of cities. China is characterized by many people's activities on the city streets in the mornings and evenings. People practice traditional Chinese physical education and dance. Basically, such activities are typical for middle-aged and elderly people. During such activities, people also communicate with each other. The authors [21, 22] note the positive and reliable effect of such exercises in improving the health and psychological state of women. Thus, Avaunt [21] analyzes the subjective state of women performing Lion Dance in Boston's Chinatown. Lion dancing is an acrobatic form of ritual performance with roots in ancient China. Traditionally, men performed lion dances to scare away evil spirits and protect themselves from evil. Members of Gund Kwok, a women's dance group in Boston's Chinatown, also perform the lion dance to counter negative energies and neutralize unwanted aggression. In their case, however, negative forces stem from the hypersexual attitudes of men to which they are exposed as Asian American women. The author believes that learning to dance the lion creates a resisting, "impenetrable" bodily subjectivity. Also, teaching and performing the lion dance fosters a sense of protection through embodied practice, as well as by reaching out and controlling the public eye. At the same time, this research is carried out in the context of studying the influence of dance training practice on individual body self-awareness.

Chang et.al. [22] found a positive reliable effect of dancing on the streets and squares of the city on the health of elderly women with mental disorders. Researchers came to similar conclusions $[23,24]$. It should be noted that the practice of mass dancing on the streets and squares is not typical for Ukraine at all, although for China it is natural and shows a positive effect on the health of middleaged and elderly people [25, 26]. Deng et.al. [27] believe that this particular practice is a key factor 
in high physical activity and health preservation in China.

Separate studies [28-30] are devoted to the health status, lifestyle and the number of injuries of dancers. For example, Dang et.al. [28] found that professional dancers had significantly lower food and alcohol consumption compared to nonprofessional dancers. Also, professional dancers have significantly lower number of injuries. The authors found that professional dance classes change the way people live.

Many studies are devoted to the therapeutic effect of dancing [31-40]. Ding et al. [31] found a positive and significant effect of dance-based mental motor activity on the quality of life of patients recovering from COVID-19. Dancebased mental-motor activity has been defined by the authors as coordinated vertical mental-motor movements that emphasize dynamic balance, structured by music or internal rhythm (such as breathing) and choreography, and which involve social interaction. The authors found that dancing has a positive and significant effect on motor function, lung function, psychological mood and other aspects, therefore dancing can be used as a safe therapy for patients recovering from COVID19. The results of this study assess the effectiveness and safety of dance-based mental motor activity in improving the quality of life for COVID-19 patients during convalescence. Similar conclusions were also reached by Kim [32] and Serlin [33].

Studies [34-37] have shown a positive reliable effect of dancing on the psychological and mental health of schoolchildren and students. Qi [35] highlighted the role of regular sports dancing in the prevention of mental disorders, including anxiety and depression, among college students. The author shows that sports dance can not only improve the quality of student learning, but also affect the healthy psychology of college students. The general level of mental health of the subjects of the experimental group was significantly higher than that of ordinary college students and ordinary people. Wang [36] found that for students with different physical fitness, the same training has a different training effect. This study demonstrates that appropriate exercise intensity and content is vital to improving physical and mental health. For participants with different physical fitness, the same training has a different training effect. This study demonstrates that appropriate exercise intensity and content is vital to improving physical and mental health. Zhang [37] showed that anxiety and depression are common among college students. This paper shows that regular sports dancing can serve as a protective factor in the prevention of depression and can be recommended for college students.

Dancing also improves the condition of patients with Parkinson's disease [38]. The authors have shown that the use of dancing significantly improves cognitive functions and memory in people with Parkinson's disease. The works [39, 40] also show a significant positive effect of dancing on the functional state of people with diseases of the cardiovascular system and metabolic disorders, in particular, those with diabetes. In patients with impaired cardiovascular activity, a significant decrease in blood pressure was noted [39]. Patients at risk of developing a "diabetic foot" showed a significant decrease in blood pressure, an increase in postural stability, and an improvement in motor functions [40].

The influence of Ukrainian dances on people's health is presented in the modern scientific literature of the rating level is insignificant. The works $[7,8]$ present data on the positive impact of the use of various teaching methods on the skill of dancers, which may also indirectly indicate an improvement in their health.

\section{Dance teaching method}

The methodology for teaching dance in China is now more and more dependent on the needs of consumers. This is due to the growing influence of capitalism in dance education in China [41]. Capitalism's involvement in dance education in China is growing rapidly, leading to significant shifts in the understanding and practice of dance education as a private business. This is contributing to the increased interconnection between dance and the economy in China, leading to a continuous increase in the commercialization of dance education. Nowadays, making a profit from dance training is perceived as a factor in increasing competition. This reinforces the consumer orientation rather than the general idea of dance art in China. Given the growing economic, political and cultural influence of China around the world, it is one of the leading factors shaping the means, methods and forms of dance education for the funding and future of dance education around the world.

With regard to the methodology of teaching dance in China, the research can be divided into two directions: 1 - the method of teaching dance to students; 2 - methodology for teaching dance teachers. In the methodology of teaching dance in China, there is currently a 
tendency to increase psychological preparation. Hong and JungKooin [42] showed the effectiveness of psychological preparation of students when teaching dance. The authors point out that at present, Chinese dance as a subject of study is still in its development stage. The authors found that many organizations focus their education solely on the study of professional knowledge and intentionally or unintentionally ignore psychological education issues such as the development of student willpower. The authors believe that the development of willpower in students affects not only individual students, but also the entire education system. This study randomly selected 30 students in the Department of Dance at Hunan University of Technology, China. The study used questionnaires, experimental methods and methods of comparative analysis. Applying the Rosenthal effect principle in this study found a positive effect of developing willpower in college and university dance instruction on confidence building in both professional dance and other areas of life. Huang et al. [43] found that limiting the time of dancers' leisure has a negative impact on the process of mastering and improving dance skills, and interpersonal limitations have a positive effect.

In the methodology of teaching dance in China, the use of new technologies, such as online training [44-46], a departure from the authoritarian style in teaching dance $[47,48]$ is currently traced. These technologies cause controversy regarding their effectiveness, but the authors who investigated this problem [44-48] point to the relevance of these technologies to the present. In Ukraine, there is also a tendency towards the use of modern technologies in teaching dance. Thus, Pyatnickaya [8] has shown the positive effect of cheer-dance for the formation of a healthy lifestyle among university students. Maryna [7] proposed an innovative method of teaching ballroom dancing.

The teaching of dance teaching at universities is also a topical study problem for Chinese researchers. Jinjing [49] proposed a new system for evaluating dance teachers when they receive qualification certificates. In this system, a more objective assessment of technical and teaching skills can be traced and indicators that can be interpreted from several positions during assessment are practically excluded. In addition, Percy and Dow [50] have shown the need for dance training for managers in the dance field as well. Xiao A. [51] showed the effectiveness of the use of Pilates in professional dance training of students.

Studies $[52,53]$ show the differences in the system of training future specialists in the field of physical education and sports, including future dance teachers, in China and Ukraine. The authors point out that in Ukraine there is a tendency towards an increase in the individual approach in teaching future teachers, which at the present stage is not yet typical for China. These authors propose the implementation of an individual approach in the process of training future specialists in the field of physical culture and sports in China.

\section{Dance styles}

The study of dance styles in both China and Ukraine is carried out in a historical context. Thus, Hee and Ju-Ok [54] analyze the development of the dance style of ChyeoYongMu. The authors note the stage when this dance was transformed into an entertaining one, and women with emphasized feminine forms began to take part in it. In general, the transformation of this dance testifies to the general trend of changing the direction of the dance art in the world: from connection with nature, the expression of various natural phenomena through dance to ordinary entertainment with a predominance of emphasis on the sexual component of dancing. It should be noted that this tendency is least of all typical for China, where the main direction of dances remains in the harmony of the soul and body, people and the sky, in the expression through the movement of the serenity of the inner state.

Dancing styles in Ukraine are distinguished by high requirements to the level of physical training of dancers, mainly to the development of speed, speed-strength qualities, endurance $[2,5,6]$. Authors who have studied Ukrainian dances call them "wild" $[2,6]$, since the level of quickness, difficult-to-coordinate jumps, the manifestation of high coordination against the background of fast execution of elements are incomprehensible for European researchers.

\section{Discussion}

This study is the first from the point of view of a comparative analysis of the process of teaching dance in China and Ukraine in terms of historical, socio-political, methodological, substantive aspects, as well as the impact of dancing on the body of the practitioners. The goal set in the study was achieved: the historical, sociopolitical, content, methodological and research features of dances in China and Ukraine were identified. These features provide a basis for the 
further development of dance art in Ukraine and China.

From the point of view of historical analysis, the origin of dances in China and Ukraine has similar features. The origin of dances in China is associated with various shamanic practices for communicating with spirits when it is necessary to solve practical problems: success in the hunt, a good harvest, victory in the war, treatment of diseases, and others [9]. On the territory of Ukraine, the first dances also emerged as a way of communication between people, and between people and gods [6]. Dancing movements also developed as a result of the imitation of the movements of animals, birds, and later - gestures that reflected certain labor processes (for example, some round dances).

However, the further development of dancing in China and Ukraine has a different direction. In China, the direction of dances to reflect the unity of man with the harmony of nature can be traced to the present day $[10,11]$. For China, both with the emergence of dances and at the present time, the internal orientation of the dance art is characteristic, that is, the orientation towards achieving harmony of the psychological state of a person through movement. In Ukraine, the internal orientation of dances gradually decreases with the historical development, the sexual orientation of dances begins to prevail, as well as purely stage skills of the dancers to attract the audience [6]. This is mainly due to the maximum amplification of the purely external effects of dances: jumps, complex coordination movements at a high speed of their execution. At the same time, the inner component of the dance begins to be lost, and the social component of the dance comes to the fore.

From the point of view of socio-political aspects, dances in Ukraine play the role of a social and political instrument, which is especially noticeable after the 1917 revolution [18]. In China, a similar trend can also be traced [17], but it is not so developed in comparison with Ukraine. This trend has influenced the development of various styles of dance art. Dance styles in China are characterized by smooth movements, a high level of concentration of dancers on their inner state [54]. Dancing styles in Ukraine are characterized by a focus on external effects that require a high level of development of such physical qualities as speed, strength, endurance, complex coordination when performing jumps and other speed-strength movements [5].

The listed aspects of the differences between dances in China and Ukraine are also reflected in studies of the influence of dances on the human body and in the methods of teaching dance art for both students and teachers. In studies on Chinese dances, the psychological and mental aspects are highly expressed in relation to the influence of dancing on the body [21, 34, 35]. Many studies are devoted to the influence of dancing on the mental health of the elderly, students and schoolchildren [21, 22, 32]. Also, in the methods of teaching dance, the emphasis is on psychological preparation. In Ukraine, the influence of dancing on the body and teaching methods are mainly aimed at studying the changes in physical qualities and motor abilities of the trainees.

In addition, China is also characterized by the practice of mass dancing in the streets and squares of the city of middle-aged and elderly people [24, 25]. Many researchers [26, 27] associate this practice with the formation and maintenance of the physical and mental health of people. This practice is not typical for Ukraine at all. Therefore, the practice of mass dancing on the streets and squares of cities can be considered as an element that can be applied in Ukraine. Among the aspects of teaching dance and dance art in general, typical for China, which can be applied in Ukraine, it should also be noted the restoration of the internal orientation of dance art towards unity with nature, towards the self-expression of people of their feelings, emotions, experiences, towards achieving harmony through movement. In our opinion, the combination of Ukrainian speedpower dance and Chinese inner focus on harmony of body and soul, on unity with nature will create a qualitatively new approach to the development of dance art in general and to the process of teaching dance.

At the same time, the emerging trend of the development of dance art in China towards externalities may also contribute to the emergence of new styles of dance. If it is possible to maintain the inner orientation of the dance art, characteristic of China, this will also lead to the emergence of new dance styles and new approaches to learning. In this regard, in teaching dance in China, the development of speed-strength qualities of dancers characteristic of Ukraine can be taken. In addition, an individual approach can be implemented in teaching dance in China, which is currently beginning to develop in Ukraine. 


\section{Conclusions}

1. In the historical aspect, the origin of dances in China is associated with various shamanic practices for communicating with spirits when it is necessary to solve practical problems: success in hunting, a good harvest, victory in a war, treatment of diseases, and others. On the territory of Ukraine, the first dances also emerged as a way of communication between people, and between people and gods. At present, China is characterized by the internal orientation of the dance art, that is, the orientation towards achieving harmony of the psychological state of a person through movement. In Ukraine, the internal orientation of dances gradually decreases with historical development. Currently, the stage skill of dancers prevails in Ukraine to attract the audience. This is mainly due to the maximum amplification of the purely external effects of dances: jumps, complex coordination movements at a high speed of their execution.

2. From the point of view of socio-political aspects, dances in Ukraine play the role of a social and political instrument, which is especially noticeable after the 1917 revolution. In China, a similar trend is also observed, but it is not so developed in comparison with Ukraine.

3. Styles of dance in China are characterized by smooth movements, a high level of concentration of dancers on their inner state. Dancing styles in Ukraine are characterized by a focus on external effects that require a high level of development of such physical qualities as speed, strength, endurance, complex coordination when performing jumps and other speed-power movements. China is characterized by the practice of mass dancing in the streets and squares of the city of middle-aged and elderly people. Many researchers associate this practice with the formation and maintenance of the physical and mental health of people. This practice is not typical for Ukraine at all.

4. In studies on Chinese dancing, the psychological and mental aspects are highly expressed in relation to the effect of dancing on the body. A lot of research is devoted to the impact of dancing on the mental health of the elderly, students and schoolchildren. Also, in the methods of teaching dance, the emphasis is on psychological preparation. In Ukraine, the influence of dancing on the body and teaching methods are mainly aimed at studying the changes in physical qualities and motor abilities of the trainees.

5. Features of Chinese dances that can be applied in Ukraine: 1 - the practice of mass dancing on the streets and squares of cities; 2 - the inner orientation of the dance art towards unity with nature, towards the self-expression of people of their feelings, emotions, experiences, towards achieving harmony through movement; 3 increased attention to the psychological preparation of dancers; 4 - high attention of researchers to the influence of dancing on the mental and cardiological health of people of different ages; high number of articles. Published in rating magazines. Features of Ukrainian dances that can be applied in China: 1 - development of speed-strength qualities of dancers; implementation of an individual approach, which is currently starting to develop in Ukraine. The combination of Ukrainian speed-power dance and Chinese inner focus on harmony of body and soul, on unity with nature will create a qualitatively new approach to the development of dance art in general and to the process of teaching dance.

6 . This study is the first from the point of view of a comparative analysis of the process of teaching dance in China and Ukraine in terms of historical, socio-political, methodological, substantive aspects, as well as the impact of dancing on the body of those involved.

\section{Acknowledgments}

We would like to express our deep gratitude for the consulting assistance in the preparation of the article to Professor Zhanneta Kozina and Assistant Professor Vitalii Korobeinik.

The study was conducted according to: research work on the topic of the Department of Olympic and Professional Sports, Sports Games and Tourism of H. S. Skovoroda Kharkiv National Pedagogical University for 2021-2026: "Development and substantiation of technologies for health promotion and harmonious development of people of different ages and social groups" (№ state registration: 0121U110053).

\section{Conflict of interest}

The authors declare that there is no conflict of interest. 


\section{References}

1. Aleksandr P. Congress of the unesco international dance council in lviv: significance and concept. National Academy of Managerial Staff of Culture and Arts Herald. 2018;(2):258-62.

2. Jordan P. From Wild Dances in Ukraine to Hard Rock in Finland: A comparative perspective. Modern Fairy Tale: Nation Branding, National Identity and the Eurovision Song Contest in Estonia. Politics and Society in the Baltic Sea Region. 2014. p. 110-33.

3. Fang X, Ryu E. The Aspects of China's Warring States Period Culture Exhibited in Korea's Traditional Dance and Music. Culture and Convergence. 2020;42(3):1136.

4. Jeon H-M, Gwi-Young B. A Study on the Life History of the Elderly North Korean Women's Emotional Purification in Memories - Access by experiencing folk dance -. The Souteast Korea Dance Society. 2020;8(1):155-73.

5. Stepanyuk I. Volyn folk dancing art and its genrestylistic features. National Academy of Managerial Staff of Culture and Arts Herald. 2016;(4):129-32.

6. Wilson A. Ukraine - Wild dances. World Today. 2004;60(11):19-21.

7. Maryna B. Regarding the methods of the preparation of the ballroom dancing performers. National Academy of Managerial Staff of Culture and Arts Herald. 2015;(4):65-9.

8. Pyatnickaya DV. Development of girl-students' physical qualities at extracurricular cheer-dance classes (cheer-dance show). Physical education of students. 2015;19(4):31-8.

9. Dambricourt-Malasse A, Cao B, You Q, Zhang P. Agro-pastoral rituals and shaman dances of Dahongyan rock painting, Guizhou, Southwestern China, new investigations. Quaternary International. 2019;507:43-52.

10. Hyun YY, Ok YJ, Kimeunhye. A Comparative Study of Korean Sword Dance and Chinese Sword Dance from the perspective of Cultural Anthropology. Korean Journal of Dance. 2020;20(2):41-54.

11. Jin J, Martin R. Exploring the past to navigate the future: examining histories of higher dance education in China in an internationalized context. Research in Dance Education. 2019;20(2):225-40.

12. Jongjin N. Formation and Diversification of Contemporary Chinese Classic Dance. 2020;42:24168.

13. Kim S-u. A Study on the Characteristics of the Court Music and Dance Monggeumcheok in the Late Joseon Dynasty. 2019;76:41-84.

14. Mengni Z, Yi Z. A Comparative Study of Chinese and Korean Court Music and Dance. Korean Journal of Dance. 2020;19(4):133-9.

15. Ouyang X, Sook KI. A Study on dance Folklore of La Lion Dance in Fengping, Hunan Province, China. 2020;41:259-90.
16. SeongHee J. A Comparative Study of Buchae-Chum between Koreans and Ethnic Koreans living in China -Focusing on dance movements and aesthetic orientation - . 2019;38:201-38.

17. Chen Z, Ju-Hee L. An Analysis of the Political Contexts of a Chinese Revolutionary Dance Drama Focused on Small-Sword Society. The Korean Journal of Dance Studies. 2021;81(1):71-81.

18. Zhuk SI. "Dances for the Masses": Revolution, Class, Proletarian Music, and Dance in Cold War Ukraine. Peddie I, editor 2020. 313-32 p.

19. Heyang T, Wang M, Rowe N. The battlefield of ballet schools: the commodification of dance education in China. Leisure Studies. 2021.

20. Gershenson O. A Dancing Russian Bear. Shofar-an Interdisciplinary Journal of Jewish Studies. 2019;37(2):71-80.

21. Avaunt C. Impermeable bodies: Women who lion dance in Boston's Chinatown. Theatre Dance and Performance Training. 2021;12(2):149-63.

22. Chang J, Chen Y, Liu C, Yong L, Yang M, Zhu W, et al. Effect of Square Dance Exercise on Older Women With Mild Mental Disorders. Frontiers in psychiatry. 2021;12:699778-.

23. Liao J, Yang Y-J, Xu D. Multiyear Square Dancing Is Associated With Superior Mental Processing Capacity But Not Memory in Middle-Aged and Older Chinese Women: A Cross-Sectional Propensity Score Matching Analysis. Journal of Physical Activity \& Health. 2020;17(7):736-43.

24. Xu J-Y, Won Y-S. The effect of Participation Motivation on Leisure Flow and Leisure Satisfaction of the middle-aged people and aged people who take part in the public square dancing in China. The Korean Society of Sports Science. 2019;28(2):71-84.

25. Liao J, Chen S, Chen S, Yang Y-J. Personal and Social Environmental Correlates of Square Dancing Habits in Chinese Middle-Aged and Older Adults Living in Communities. Journal of Aging and Physical Activity. 2019;27(5):696-702.

26. Peng F, Yan H, Sharma M, Liu Y, Lu Y, Zhu S, et al. Exploring factors influencing whether residents participate in square dancing using social cognitive theory A cross-sectional survey in Chongqing, China. Medicine. 2020;99(4).

27. Deng C, Feng R, Kong L. Square Dance the Key Factor of the Elevating Prevalence of Physical Activity in China. Iranian Journal of Public Health. 2019;48(10):1920-1.

28. Dang Y, Koutedakis Y, Wyon M. Fit to Dance Survey: Elements of Lifestyle and Injury Incidence in Chinese Dancers. Medical Problems of Performing Artists. 2020;35(1):10-8.

29. Liyansen, Hyun-Ryun K, 호소용. The Structural Relationship between Participation Motivation, Commitment, and Intention to Continue Participation in Traditional Chinese Sports: Focusing on Dragon Dance Participants. The Korean Journal of Sport. 2021;19(1):247-58. 4 
30. Tong A-N, Zhang J-W, Zhou H-J, Tang H-H, Bai J-Z, Wang F-Y, et al. Ischemic damage may play an important role in spinal cord injury during dancing. Spinal Cord. 2020;58(12):1310-6.

31. Ding Y, Guo C, Yu S, Zhang P, Feng Z, Sun J, et al. The effect of dance-based mind-motor activities on the quality of life in the patients recovering from COVID19 A protocol for systematic review and meta-analysis. Medicine. 2021;100(11).

32. Kim D-H. A Study on the Untact Dance Practical Classes in Universities in the COVID-19 Era. The Korean Journal of Dance. 2020;78(5):37-61.

33. Serlin IA. Marian Chace Foundation Lecture 2020 Trauma-Informed Dance Movement Therapy: Real Life Trainings with Syrian Refugees, China and US COVID-19 Hotline. American Journal of Dance Therapy. 2021;43(1):64-76.

34.Jung K-I, Qiang YZ, Choi H. A Study Regarding Improvement of Psychological Health Promotion for Child Requiring Protection in China through a Dance Education Program. Korean Journal of Teacher Education. 2021;37(1):265-83.

35. Qi J. Investigation and analysis of the influence of sports dance based on wireless network mode on college students' mental health. Revista Brasileira De Medicina Do Esporte. 2021;27:70-2.

36. Wang Z, An G, Zhang W, Yang G. The effect of jazz dance on physical and mental health of students with different physical fitness. Journal of Sports Medicine and Physical Fitness. 2019;59(5):880-5.

37. Zhang L, Zhao S, Weng W, Lin Q, Song M, Wu S, et al. Frequent Sports Dance May Serve as a Protective Factor for Depression Among College Students: A Real-World Data Analysis in China. Psychology Research and Behavior Management. 2021;14:405-22.

38. Zhang Q, Hu J, Wei L, Jia Y, Jin Y. Effects of dance therapy on cognitive and mood symptoms in people with Parkinson's disease: A systematic review and meta-analysis. Complementary Therapies in Clinical Practice. 2019;36:12-7.

39. Peng Y, Su Y, Wang Y-D, Yuan L-R, Wang R, Dai J$\mathrm{S}$. Effects of regular dance therapy intervention on blood pressure in hypertension individuals: a systematic review and meta-analysis. Journal of Sports Medicine and Physical Fitness. 2021;61(2):301-9.

40. Zhao Y, Cai K, Wang Q, Hu Y, Wei L, Gao H. Effect of tap dance on plantar pressure, postural stability and lower body function in older patients at risk of diabetic foot: a randomized controlled trial. Bmj Open Diabetes Research \& Care. 2021;9(1).

41. Heyang T, Martin R. A reimagined world: international tertiary dance education in light of COVID-19. Research in Dance Education. 2020.

42. Hong C, JungKooin. A Study Regarding Dance Majors Willpower Development based on the Rosenthal Effect. Korean Journal of Teacher Education. 2019;35(2):255-67.
43. Huang G, Cheng L, ByungChan L. The relationship between Leisure Constraints and Leisure Constraints Negotiation Strategies of Square Dance activities in china. The Korean Society of Sports Science. 2021;30(2):107-16.

44. Liu T. Video Games as Dating Platforms: Exploring Digital Intimacies through a Chinese Online Dancing Video Game. Television \& New Media. 2019;20(1):3655.

45. Ma F, Guo C. Research on Dance Teaching Mode Based on Flipped Classroom in the Internet +Age. Informatica-Journal of Computing and Informatics. 2019;43(3):331-6.

46. You Y. Online technologies in dance education (China and worldwide experience). Research in Dance Education. 2020.

47. Rowe N, Xiong X. Cut-Paste-Repeat? The maintenance of authoritarian pedagogies through tertiary dance education China. Theatre Dance and Performance Training. 2020;11(4):415-31.

48. Rowe N, Xiong X, Tuomeiciren H. Dancing from policy to pedagogy in China: Transgressions, surveillance and resistance from students, teachers and institutional leaders. Policy Futures in Education. 2020;18(8):995-1010.

49. Jinjing C. A Study on The Problems of Teacher Qualification Certificate in China's Dance Grade Examination System. The Korean Journal of Dance Studies. 2019;75(3):153-80.

50. Percy W, Dow K. The coaching dance applied: training Chinese managers to coach. Coaching-an International Journal of Theory Research and Practice. 2021.

51. Xiao A. Analysis on the Trend of Researches on Pilates for Applying Physical Training to Korean and Chinese University Students Majoring in Dance. Official Journal of the Koeran Society of Dance Science. 2021;38(2):13-28.

52. Xiaofei W, Korobeinik V, Kozina Z. Features of the organization of teaching for future physical education teachers in the People's Republic of China and the possibility of implementing an individual approach in their training: a review article. Zdorov'â, sport, reabìlitaciâ [Health, Sport, Rehabilitation]. 2021;7(2):8-17. https://doi.org/10.34142/HSR.2021.07.02.01

53. Kozina Z, Korobeinik V, Safronov D, Xiaofei W. Effect of the individual approach application during the training of future physical education teachers on the degree of student satisfaction with the learning process in the People's Republic of China. Journal of Physical Education and Sport. 2021;21(5):1234-1242

54. Hee KK, Ju-Ok B. Dance Style Transformation of ChyeoYongMu, Dance of Yeon San Gun. The Journal of Korean Dance. 2019;37(2):25-49. 


\section{Information about the authors}

\section{Zhang G.}

408832453@qq

https://orcid.org/0000-0002-1298-7725

Lishui University

Xueyuan Road, Lishui, Zhejiang, China, 323000

Чжан Г.

\section{Інформація про автора}

408832453@qq

https://orcid.org/0000-0002-1298-7725

Лішуйський університет

вулиця Сюйюань, р-н Ліанду, м. Лішуй, провінція Чжецзян, Китай: 323000

Чжан $\Gamma$.

\section{Информация об авторе}

408832453@qq

https://orcid.org/0000-0002-1298-7725

Лишуйський университет

улица Сюйюань, р-н Лианду., г. Лишуй, провинция Чжэцзян, Китай: 323000

This work is licensed under a Creative Commons Attribution 4.0 International License (CC BY 4.0)

Received: 2021-12-08 Accepted: 2021-02-09 Published: 2021-25-09 